Academic Platform Journal of Engineering and Science

journal homepage: http://apjes.com/

\title{
Ancient Karez System in Afghanistan: The Perspective of Construction and Maintenance
}

\author{
${ }^{1}$ Abobakar Himat, ${ }^{* 1}$ Selim Dogan \\ ${ }^{1}$ Department of Environmental Engineering, Konya Technical University, Konya, 42031, Turkey \\ selim@SelimDogan.com \\ abobakar.himat@gmail.com iD \\ Research Paper \\ Arrival Date: 02.10.2018 \\ Accepted Date: 29.03.2019
}

\begin{abstract}
Ancient Karez has a history of millennium. Karez is underground tunnel which is constructed in ground by digging the main well of the system and extending underground tunnel in foothills of the mountains. This system extracts groundwater to surface by gravity without using any pumping equipment. Ancient Karez system is viable in hot, arid and semi-arid climate regions. These systems are one of the best ways of extracting groundwater by gravity in such poor regions. Minimum slope is vital for extracting groundwater to the surface in Karez system. In this study, the perspective of construction and maintenance of Karez system in Afghanistan is assessed. Information related to Karez construction and maintenance is provided in order to improve the quality of work during these processes. The Karez system cannot be used effectively if construction and maintenance processes are not carried out properly. This will affect agricultural productions, water supply and social life in the region. Some possible solutions are suggested for the mitigation of the risk of collapsing and extinction of Karez systems. Some recommendations are provided to encourage the associated organizations in Afghanistan for rehabilitation of Karez irrigation and water supply system.
\end{abstract}

Keywords: Ancient water supply, arid climate, irrigation system, Karez, Qanat.

\section{INTRODUCTION}

Ancient Karez is environmentally friendly and sustainable irrigation and water supply system in rural Afghanistan. Karez is durable and gravity-driven system with continuous flow. Most of water supply systems including rural infrastructures such as Karez systems have been damaged and destroyed during the past three decades of war and civil conflicts in Afghanistan [1]. Wars, drought and social collapse disrupted land management and agricultural production systems in (Khost, Paktika and Paktya provinces) southeastern parts of Afghanistan [2]. Significant destruction of cultural heritage occurred as a consequence of war and civil conflict in South Central Asia and the Middle East [3].

The Karez systems irrigate about 163,000 ha of land with 6000-7000 individual Karezes throughout Afghanistan [45]. The extinction of ancient Karez water supply has been happening in all over the world. According to Hussain et. al. [5], 60-70\% of the Karezes are not in use due to drought and low groundwater recharge. Out of total 5887 recorded Karezes in Afghanistan only 11\% (611) were identified as being active and $89 \%$ (5276) as inactive [3]. There are several reasons for Karez extinction [6]. The reasons for Karez extinction are environmental and socio-economic effects. The reason of abandonment of traditional structures is that modern structures involve fewer amounts of work and maintenance than traditional structures [7]. The origin of Karez is not known, some researcher has been proposed that the origin of Karez (Qanat) construction was in Persia more than 2500 [8-10] or 2800 [11] or 3000 [12-16] years ago.

Karez is common water extraction technique in such regions where surface water is not available. The initial impact of Karez system on human-environment relations is best examined in hot and arid regions of the world [17]. The rural Afghan inhabitants which are living in remote regions of the country, where rivers are not available rely upon groundwater delivered from Karezes [18]. Location map of Afghanistan and concentrated Karez region of the country is illustrated in Fig. 1.

The water table is shallow in the foothills of mountains. The flow path of groundwater can be interfered by installing the main well of Karez in unconfined aquifer. The extracted water from the main well can be transported to the surface

${ }^{* 1}$ Corresponding Author: Department of Environmental Engineering, Konya Technical University, Konya, 42031, Turkey, selim@SelimDogan.com, +905326347178 
by gravity via underground channels [19]. Constructing Karez is difficult; however, Karez is long lasting once it is constructed. Karez is underground conduit with a gentle slope to transport water from an unconfined aquifer to surface by gravity for irrigation, livestock and other water supply purposes. Karez systems tap into subterranean water in a manner that efficiently delivers large quantities of water to the surface. The water is transported downstream by the gravity in channels from a source which is typically an upland unconfined aquifer. Karez systems allow water to be transported over long distances without much loss via evaporation.

The Karez systems are not well resistant to natural disasters; e.g., earthquake and flood. There is need for risk assessment of Karez to protect these structures from damages and collapsing. The significant source of Karez extracted water is melted snow water, so it can be also counted as less polluted water source due to human contamination. Generally, the Karez systems have been in rural areas away from polluted city centers, thus the groundwater quality itself might be good in terms of anthropogenic pollutions. The Karez system could supply considerably good quality of fresh water than most of surface water for human consumptions. Natural treatment process occurs during the snow melt water infiltration. There is no need for further water treatment for many cases.

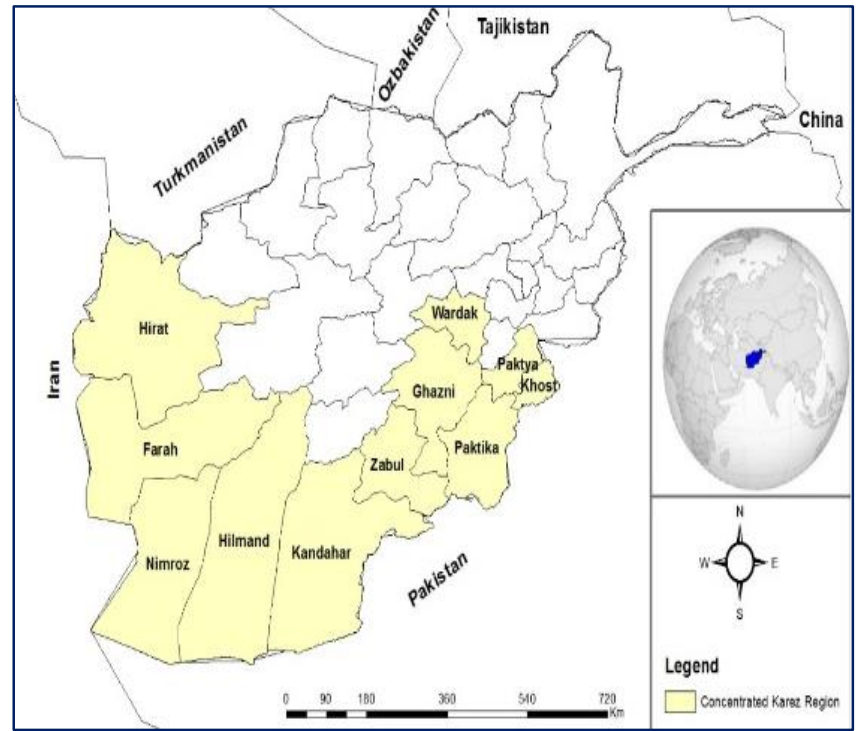

Fig. 1. Location map of Afghanistan and concentrated Karez region

In this study, the perspective of Karez system construction and maintenance measures in Afghanistan are assessed. Recommendations are provided in order to encourage the associated organizations for taking cautions in terms of improvement of cleaning and maintenance of these ancient water supply systems. The objective of this study is to assist the effective use of Karez system which maintains the agricultural productivity and revival of socioeconomic life beside the prevention of the accidents that cause the injuries or loss of lives of the workers. The connection between migration and revival of socioeconomic life is then discussed.

\section{THE FUNCTIONS OF ANCIENT KAREZ SYSTEM IN AFGHANISTAN}

Karezes are ecologically sustainable systems with a substantial potential in water supply in order to reduce the negative consequences of global water deficiency especially in the dry and arid regions [20]. Karez systems have two main functions; which are water supply (technical) and social [21]. Groundwater is the primary source for irrigation and water supply in most parts of Afghanistan. Groundwater contamination map of Afghanistan due to natural factors is shown in Fig. 2. The groundwater of the country might be polluted by natural contaminants such as; Arsenic, Boron, Fluoride and Sulfate as shown in Fig. 2.

The southwestern region of concentrated Karez areas of the country is free of Arsenic contamination except Ghazni, Wardak and northwestern Heart province.

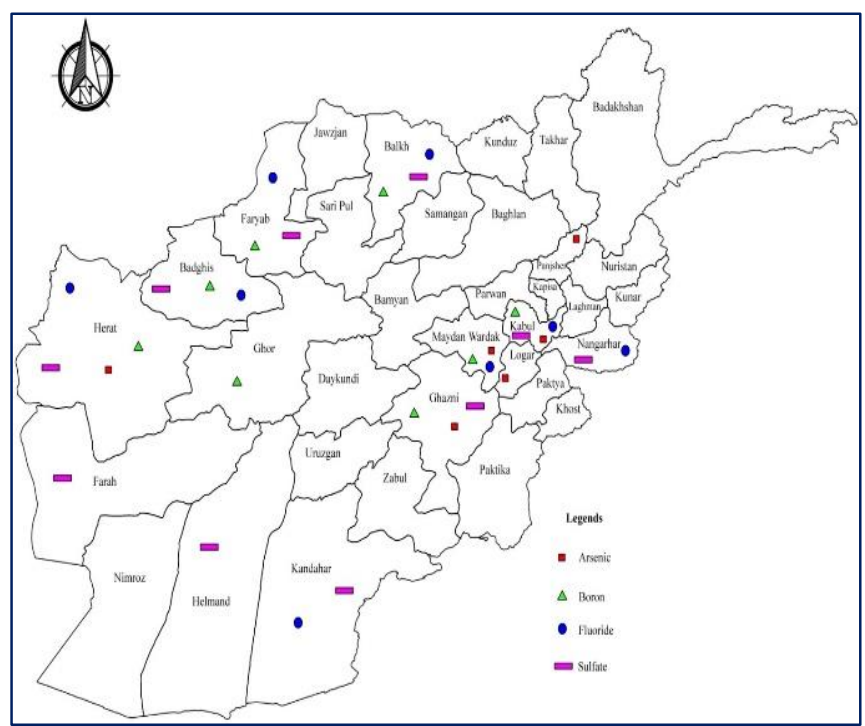

Fig. 2. Natural factors of groundwater contamination of Afghanistan [22]

Sufficient water resources are not available in most regions of the country. Inadequate water resources and unsustainable practices of irrigation have dramatically depleted the groundwater level and dried up Karez systems which resulted in loss of local community control over water resources [23]. The absence of a reliable water supply to farmers is the most significant obstacle to food security and agricultural development in Afghanistan [24]. Agricultural activities without a proper water management system may be possible in temperate humid areas; however, agricultural activities may not be possible without a proper irrigation system in dry regions [25]. Arid climate of southwestern and lack of surface water is the main reason for concentrated Karez existence in these regions of the country. The ecoenvironmental water demand is provided by groundwater due to the lack of precipitation. The groundwater is recharged by seepage from streams, canals and fields in dry 
regions [26]. Most of rural communities in Afghanistan don't have access to tap water and there is absence of state-owned irrigation infrastructures. The residents are supposed to manage water by their own community traditions. Farmers in Afghanistan reserve the water of Karez in small water storage ponds at nights and irrigate their farmlands in the early morning in order to minimize the evaporation losses while growing crops during the summer and spring seasons. The water of Karez is shared among farmers by local community based decisions. The owners of farmlands have share by rotational basis. Generally, the time of rotation varies between 1-2 weeks.

Main well is the source of water and provides most of the water for Karez (Fig. 3). The numbers of main well of Karez should be increased during the dry periods and drought years to provide more water for rural communities. Installing the main well in the foothill of the mountains is very difficult that needs experience and some knowledge about the groundwater route. Karez system would fail in cases the main well is not installed in the shallowest aquifer of the area.

The length of Karez is directly related to the characters of the Main well. Underground channel of Karez would be longer in case the main well is deeper. This may cause the system not cost-effective due to the construction, maintenance and cleaning costs of Karez which would take more time and more labor force.

The slope of terrain is also important factor for Karez's length. If the terrain is steeper the length of Karez would be short. If the terrain is flat, so the length of Karez would be long. The length of Karez also depends on the water table. There is requirement of experimental works for understanding the favorable slope for Karez water transportation channel. Extracting water to the surface gets easier by gravity in the shallow water table. The underground channel of Karez should be shorter in regions with shallow water table. It is more difficult to extract water to the surface by gravity when the water table is deeper.

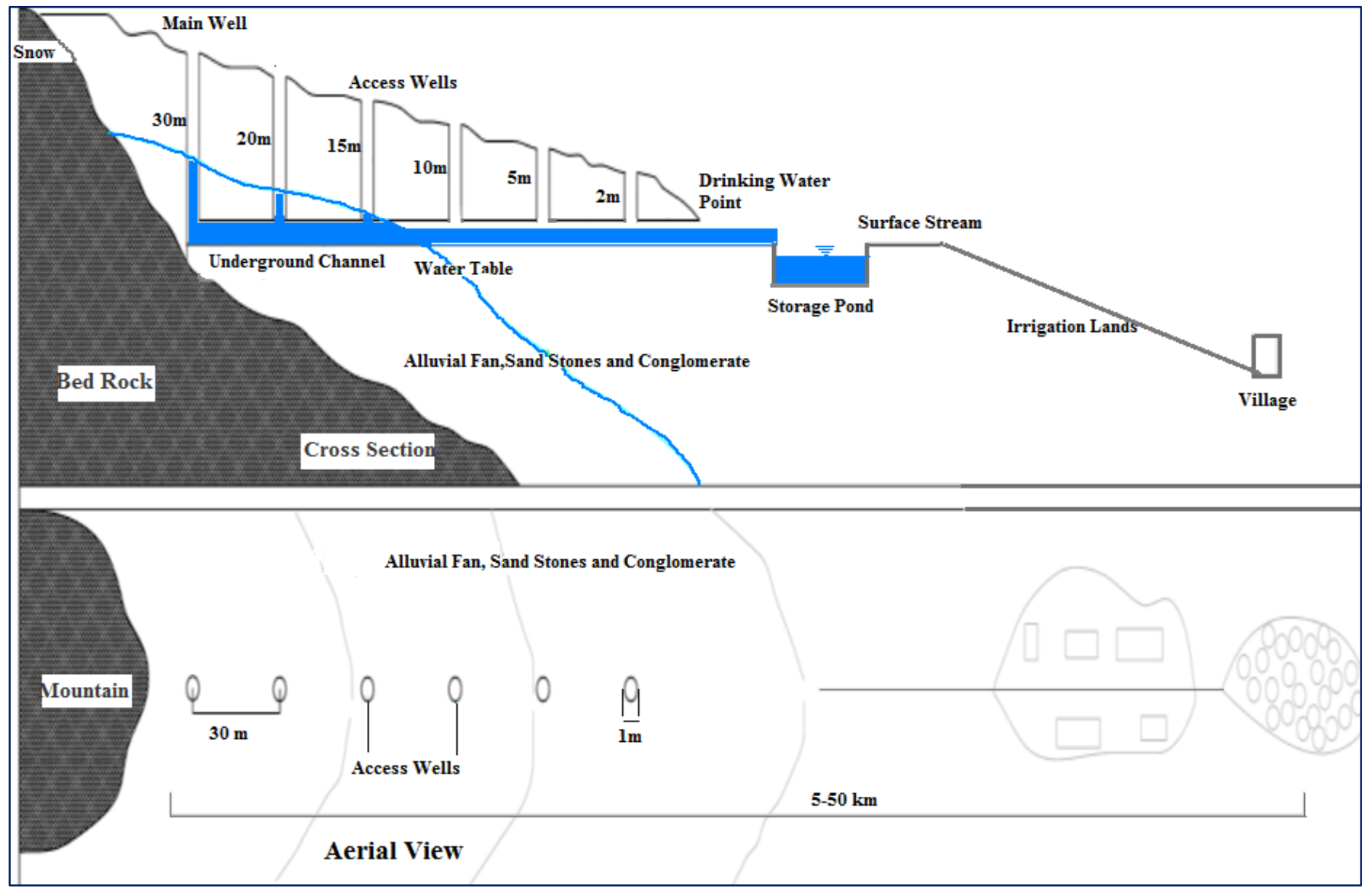

Fig. 3. A Karez cross-section and plan

The access wells are also vital as oxygen supplier to underground Karez workers. In Afghanistan the distance between two access wells is typically 30 meters, however, varies between 15-35 meters due to the soil structure, geological and topographical characteristics of the region. The distance between two access wells should not be exceeded. Exceeded distance between two access wells would make the system prone to collapse and dangerous for Karez workers. Karez workers used oil lamps in underground tunnels in the last decades; however nowadays they use torches. The use of oil lamps in long and deep underground tunnel is more imminent danger. 
Sometimes Karez systems are confused with natural water springs. Some farmers expand the mouth of spring for more water supplies, so in this situation expanded spring mouth may look like a drinking water point of a Karez system. There are some differences between Karez and natural spring. Karez systems have access wells and underground water transportation tunnel and Main well, in contrast to the spring that does not have such components. The transportation of water is in surface canal in natural water springs; however, water flows in underground channel in Karez system.

\section{COMPONENTS OF KAREZ SYSTEM}

The components of Karez system are; (1) main well (Sarchah), (2) infiltration part of the tunnel, (3) water conveyance part of the tunnel, (4) open channel, (5) access wells (Chah), (6) small storage pond (Hawz), (7) the irrigation area, (8) sand and gravel, (9) layers of soil, (10) drinking water point(Awkhura) [27]. Karez system has three technical functions; a) water collection (underground), b) water transportation (underground and surface), c) water distribution (surface) [27].

Some major components of Karez system are illustrated in Fig. 3. In this system the most crucial parts are: Main well, underground channel, access wells and drinking water point respectively. The deposit of snow in mountains is vital for feeding the main well of the system. Most of the precipitation occurs as snow during the winter. The accumulated snow on the mountains melts during the spring and summer seasons. The melted snow feeds the Karez dug unconfined aquifers.

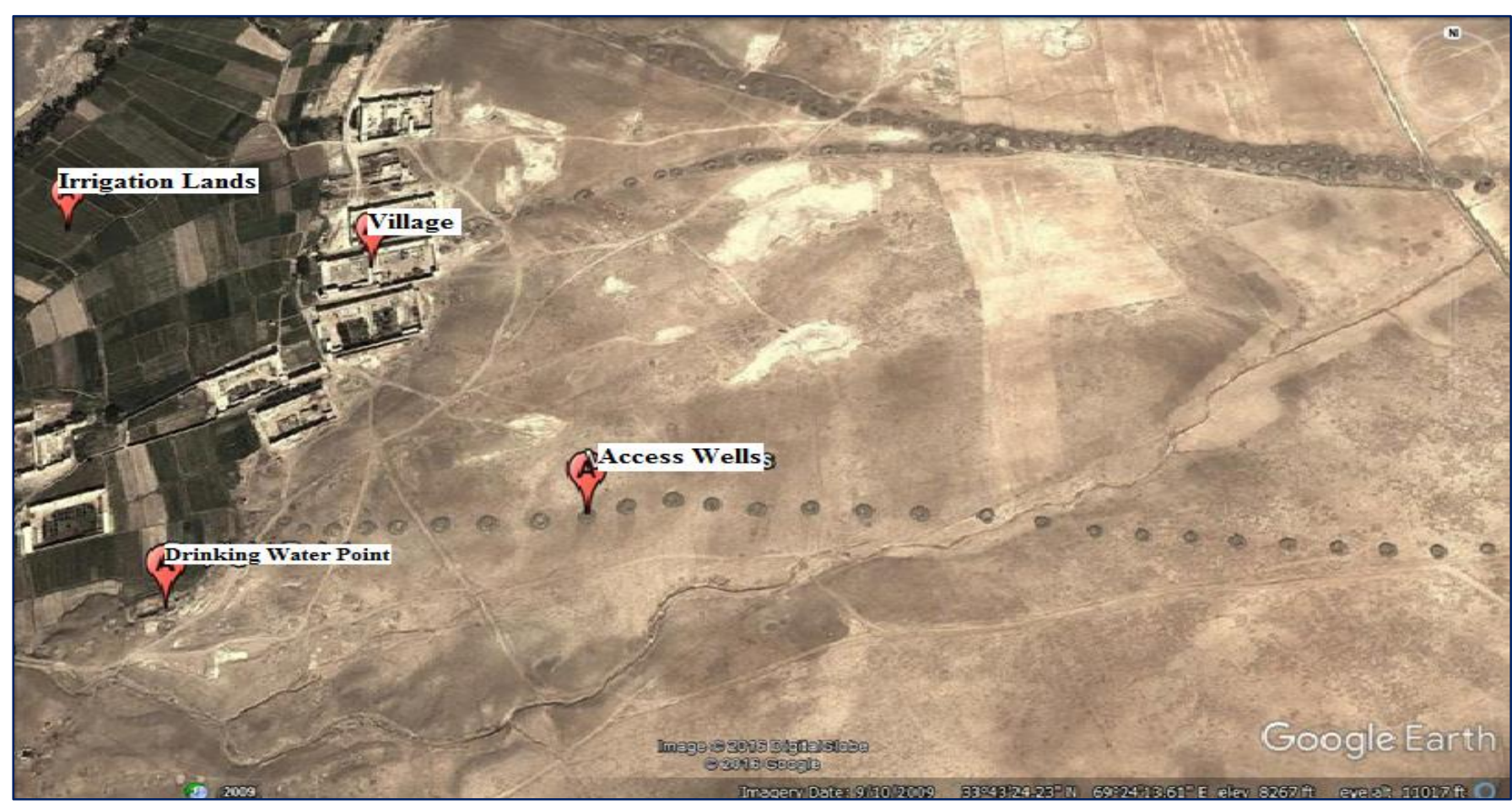

Fig. 4. A group of Karezes, a village and irrigated area in Paktia province of Afghanistan [map data: Google, Digital Globe]

Aerial view of three series of Karezes with access wells, drinking water point and the village beside irrigated area in Paktia province of southeastern Afghanistan is illustrated in Fig. 4.

\section{CONSTRUCTION OF KAREZ}

Geographical, hydrological and topographical maps of the site should be taken into consideration prior to the Karez construction. The knowledge about local hydrology, geography and topography and social conditions are essential for applying historical and traditional structures [7]. The Karez system must be constructed away from the earthquake fault lines and high risk regions of flood. Afghans have used Karez systems for irrigation, livestock and domestic water supply purposes for millennium [28]. The reasons for Karez construction are; the absence of surface water resources (streams, rivers, lakes), being in an undeveloped remote region, inadequate precipitation, high evaporation and poor financial conditions. These severe conditions rural inhabitants of the country have forced to dig Karez systems in their communities for getting access to water. Karez system is constructed as the series of access wells connected by gently sloping tunnels. Karez systems dug and constructed by professional Karez workers (Karezkan) with manual labor system. There are two kinds of workers for Karez construction and maintenance; a) Skilled Karez labors; which generally work underground, b) Unskilled Karez labors; which usually work in surface. Underground workers are more vulnerable to the risks of injuries and death.

There are three types of Karez in rural Afghanistan; a) Long Karez, b) Short Karez c) Tailed Karez [27]. Short and tailed 
Karezes are not common in Afghanistan. The most common type of existing Karez in the country is long Karez system. The type of Karez is selected due to geographical, physical, topographical, hydrogeological and hydrological conditions of a region which might be a function of the depth of water table, soil properties and slope of terrain. The southwestern region is covered by; conglomerates, sand, loams, sandstones, siltstones, volcanic rocks, limestones, shales and dolomites as shown in Fig. 5.

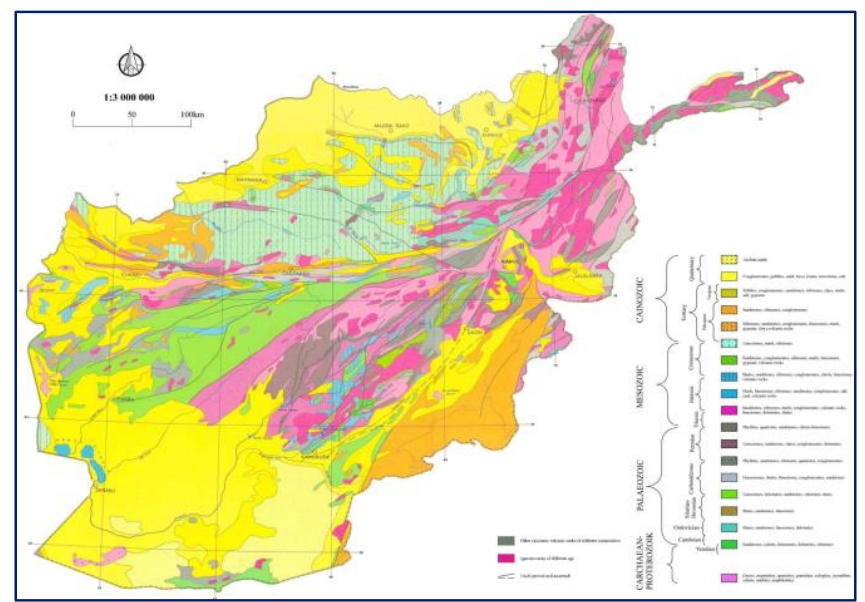

Fig. 5. Geological map of Afghanistan [29]

The installation of main well is the most important part of the system. There are some local experienced Karez workers which are responsible for determination of suitable place for main well of Karez. The most important point for determination of suitable place for main well is to find the shallowest unconfined aquifer for digging the main well.

The most challenging task is to install access wells on a straight line during the construction of Karez system. The access wells on the surface may look lined up very smoothly, however, the underground tunnel is very uneven and complicated. During the excavation process in underground tunnel, in some cases Karez workers faced with big firm rocks in tunnel due to these big firm rocks the workers change their route. This is one to the reason of underground tunnel unevenness. The complexity and unevenness of tunnel make the Karez system more difficult and dangerous for construction, maintenance and cleaning processes. The main purpose of access wells is ventilation. The access wells have also very important role during cleaning and maintenance of Karez system. Adequate drainage system is also important in the surface of Karez near to access wells for protecting the Karez from flood and entry of other contaminants.

\section{MAINTENANCE OF KAREZ}

The maintenance of Karez is the excavation process which is carried out by Karez workers in order to protect the system for sustainable uses. Sustained maintenance is crucial for preservation of the Karez system [7]. The protection of Karez is economic and social necessity for rural poor communities
[30]. The cleaning and maintenance of Karez system is duty of the concerned community, however some national and international organizations support communities for rehabilitation of Karez systems for a better use. Maintenance of Karez system is crucial in order to use this water supply system in a better way with a minimum water loss. Water distribution in Karez system is respectively effective, however, there is still room for further improvement in order to minimize water losses while transportation which may maximize the available water supply and agricultural productions [31].

The following routines should be undertaken for Karez cleaning and maintenance:

- Cleaning of silt and deposited debris from underground channel,

- Opening and cleaning of access wells,

- Removing collapsed materials from underground tunnel,

- Repairing underground tunnel,

- Repairing access wells,

- Rerouting the underground tunnel where the cleaning of tunnel is impossible and dangerous.

The team of workers for Karez cleaning and maintenance generally comprises from four Karez workers. Two of them generally work in underground and two of them work in the surface. The low stability of the structure and high risk of collapse make Karez system more difficult for further excavation and restoration [32]. The underground workers are more prone to risk than the surface workers are.

Clogging of underground channel in Karez due to deposited silt is one of the biggest problems which threatening the durability of the system. Most of the silt is dropped from the access wells and underground channel walls to the underground channel bed. As an alternative solution, a dry stone masonry should be carried out in Karez access wells and underground channel walls for protecting the underground channel bed from clogging. Dry stone masonry also carried out in order to maintain damaged and collapsed access wells and underground tunnel walls. Experienced workers are required for cleaning and maintenance of Karez.

The flow direction of water in Karez in underground channel is from upstream (main well) to downstream (drinking water point). The water flow in the bed of channel would help Karez workers to transport some deposited silts from upstream to downstream easily via water flow. Thus, the cleaning process of Karez should starts from main well through the drinking water point downstream. Generally the main well of the system installs in the foothill of mountains and extend the channel with installing access wells downstream to the flat areas. Thus, the depth of main well is bigger than the access wells.

\subsection{Improvements of Karez Maintenance}

Ancient Karez systems are locally developed systems without any installed equipment. Locally available materials 
are used for maintenance of these systems. Stones and timbers are available in every part of Afghanistan. Installing stones protect the system from flood damages and help to minimize the erosion of access wells. Installing timbers can protect the system from collapsing during the maintenance periods. Installation of timbers is also vital for occupational health and safety.

There is need for conducting some field studies for improvement of Karez maintenance practices. Therefore, experimental work should be carried out for improvement of Karez maintenance. There is a list of some possible improvement opportunities for Karez maintenance:

- Capping of access wells with stone masonry and other local available materials to protect access wells from flood and another materials entry,

- Improvement of surface channel by pitching stones and other local available materials,

- Capping of storage ponds with local available impermeable layers.

Some equipment for Karez construction and maintenance should be provided; leather/rubber bucket (Salwargha), string, wheel and pulley, wheel barrow, pick, shovel, sledgehammer, torches etc. Leather/rubber bucket is locally available and use for cleaning the Karez system.

The weight of leather bucket with wet debris varies between $40-50 \mathrm{~kg}$. Generally the shape of leather bucket is circular truncated cone. In most cases the dimensions of the leather bucket are; $\mathrm{d} 1=0.15 \mathrm{~m}, \mathrm{~d} 2=0.35 \mathrm{~m}, \mathrm{~h}=0.50 \mathrm{~m}$. The capacity of leather bucket can be calculated as 30 liters.

The team of Karez workers consists of four Karez workers. Two of them work on the surface and two of them work underground. The duty of each worker is as follows; in underground channel, one of the workers is responsible for excavation and the other one is responsible for excavated material delivery to the surface. In surface, both of the workers are responsible for extracting the excavated materials by pulley from tunnel to the surface. Two of leather buckets are generally used in construction and maintenance process.

\section{KAREZ OPERATIONS}

Ancient Karez is a system of many advantages; however, there are some Karez related problems. Some Karez related problems and possible solutions are provided in Table 1.

Table 1. Karez related problems and suggestions for possible solutions

\section{Problems}

Insufficient water flow

Losses of water from storage ponds

Conflict between upstream and
downstream stakeholders

Water losses in surface channel by evaporation and infiltration

Extinction of Karez systems

\section{Possible Solutions}

Extend the number of main wells, Clean and maintain the system periodically

Store the water during the nights to avoid evaporation losses and use it during the day for irrigation and water supply purposes

Share Karez water between upstream and downstream users fairly

Impermeable layer should be installed under the surface channel for infiltration losses,

Farmers should try to irrigate their farmlands in the early morning Prevent drilling deep wells,

Educate new generation about the importance of these ancient systems,

Train professional Karez workers for Karez maintenance

Difficulty and danger of Karez system. A contamination of geological formation and in some cases microbial contamination from snakes and reptiles

Prone to collapse and damage

Train the Karez workers about occupational health and safety, use occupational safety equipment.

Maintain the system seasonally and periodically

Protect the system from collapsing and damages by installing local available materials (timber and stones)

Reduction in discharge in consequence of depletion of unconfined aquifer

Cleaning and maintenance cost

Prevent drilling deep wells in concerned areas

Use locally available materials in access wells of Karez to minimize the effects of erosion

\section{ADVANTAGES OF KAREZ SYSTEM}

Karez is the system of extracting groundwater to the surface without using any equipment. Karez systems should extract water with good quality than most surface water qualities, which allows community to manage these water sources for different purposes.
The list of some highlighted advantages of this ancient water supply system is given below.

- Saving energy; there is no need to any energy-required equipment.

- Low carbon footprint; there is no need for any fuel consumption.

- Efficiency; Transportation of water without any evaporation losses and minimum infiltration rate. 
- Convincing water quality; the extracted water is free of atmospheric hazards.

- Natural treatment of water during infiltration process; the transportation occurs mostly in underground tunnel.

- Sustainability; Durable and continuous flow, some amount of water is always available even in dry periods.

- No depletion of water table; there is no excessive usage possible. This makes the Karez system more sustainable than other groundwater extraction systems such as pump equipped wells which may deplete water table.

- Sufficient consumption of water without paying any water related bills.

- Suitable and viable tool for irrigation, livestock and water supply remote regions for undeveloped countries.

- Provides solidarity in social life; common sense of belonging to a concerned community.

- World heritage in peaceful water management. Traditional community-based water management system.

- Inexpensive maintenance.

\section{KAREZ AS A TOOL OF INCOME FOR RURAL WORKERS}

In Afghanistan adult men of rural families are responsible to work and earn money for their family members. They usually work in their own farmlands and other farmlands for earning money. Many local workers in rural areas of the country have to work for low wages. There would be a good opportunity for rural workers to support agricultural production by operating this ancient water supply system. Due to the low wages in rural areas, rural workers have to migrate to the urban areas of the country and also to foreign countries for better employment opportunities. The operation and new construction of traditional hydraulic structures can be an option to employment opportunities for rural workers and it will reduce the migration rate from rural to urban areas [7]. The surface water resources are not sufficient for irrigation, livestock and domestic water supply purposes in most part of the country. The scarcity of water resources, rural inhabitants of the country forced to rebuild and maintain the ancient Karez system for sufficient water supply purposes. Afghanistan is an agricultural country and most of the agricultural productions come from irrigated agriculture. Thus, sufficient water is crucial for agricultural activities. In recent years migration is an internationally overwhelming issue. Afghans are currently ranked the second largest refugee nation with 2.5 million refugees after Syrians [33]. Creating employment opportunities in agriculture sector especially in rural areas might decrease the rate of Afghan refugees.

\section{CONCLUSIONS}

The local community is responsible for Karez system rehabilitation without getting any help from the central government. The central government and other international organizations should give some funds for rehabilitation of these ancient water supply systems and implement some projects in rural areas of the country. Thus, for creating such employment opportunities in rural areas of the country the rate of migration from rural to urban and foreign countries should be decreased.

The construction of new Karez systems may not be costeffective, but the rehabilitation of existing Karez systems should be. The rural communities may rehabilitate the existing Karezes rather than constructing of new Karezes. Most of the Karezes are under the threat of extinction throughout the country. Further field projects should be carried out to discover the best rehabilitation practices for Karezes in order to revitalize these ancient systems countrywide.

There are no adequate fruit storage facilities in most of the rural areas. Most of the fruit and other vegetable crops are not stored in these regions due to the absence of storage facilities. Therefore, the locals are forced to sell their products under real market value. Karezes can be used as cooling storages for those crops in such regions.

As a result of field experiences and general evaluations, the following suggestions are given in order to manage the Karez systems properly:

- There is need for "Ancient Water Infrastructure Conservation Union" in governmental organizations which they should be responsible for Karez systems rehabilitation. Proposed union may create detailed fitfor-purpose guidelines for the construction, maintenance and rehabilitation of Karez systems. Union may also work as extension center in order to educate occupational health and safety measures to Karez workers.

- Artificial recharge applications such as; managed aquifer recharge, rainwater harvesting and aquifer storage and recovery should be carried out in areas where Karez systems are not able to supply sufficient water for rural communities.

- The government and associated organizations related to water resources management should prioritize the rehabilitation of Karez system rather than constructing new water supply infrastructures, especially drilling deep wells. Deep wells do not only frustrate the solidarity of community due to the unfair use of water by limited people instead of whole community as the exploitation of the source, these deep wells mostly exacerbate the condition of water potential for the Karezes.

- Migration is currently one of the top global issues and a very important challenge for both regional and global scale. The employment opportunities are very limited in rural Afghanistan, which substantially depend on agricultural activities. Good management practices of Karez systems in the country would increase water availability for livestock, domestic uses and agricultural activities. Thus, creating employment opportunities in rural areas of the country would be a part of solution for migration problems. 


\section{REFERENCES}

[1] A.S. Qureshi, "Water Resources Management in Afghanistan: The Issues and Options" (Working Paper 49) IWMI. Pakistan Country Series, vol.14, pp.5-15, (2002).

[2] J.W. Groninger, and R.J. Lasko, "Water for agriculture: Challenges and opportunities in a war zone", Water international, vol.36, no.6, pp. 693-707, 2011.

[3] P.T.Stinson, M.C. Naglak, R.D. Mandel, and J.W. Hoopes, "The Remote-Sensing Assessment of a Threatened Ancient Water Technology in Afghanistan", Journal of Archaeological Science: Reports, vol.10, pp. 441-453, 2016. [4] A. Azimi, and D. Mccauley, “Afghanistan's Environment in Transition", $1^{\text {st }}$ Edition. Asian Development Bank, Manila, Philippines, pp. 1-12, (2002).

[5] I. Hussain, O.S. Abu-Rizaiza, M.A.A. Habib, and M. Ashfaq, "Revitalizing A Traditional Dryland Water Supply System, The Karezes in Afghanistan, Iran, Pakistan And the Kingdom of Saudi Arabia", Water International, vol.33, no.3, pp. 333-349, 2008.

[6] B. Remini, R. Kechad, and B. Achour, "The collecting of groundwater by the qanats: A millennium technique decaying”, Larhyss Journal, no.20, pp.259-277, 2014.

[7] K. Röttcher, "Combination of Tradition and the Modern Age: New Methods for Efficient Water Management", Irrigation and Drainage, vol. 62, no.3, pp. 315-321, 2013.

[8] P.W. English, "The Origin and Spread of Qanats in the Old World", Proceedings of the American Philosophical Society, vol.112, no.3, pp.170-181, 1968.

[9] P. Beaumont, "Qanat Systems in Iran", Hydrological Sciences Journal, vol.16, no.1, pp.39-50, 1971.

[10] H. Ahmadi, A.N. Samani and A. Malekian, "The Qanat: A Living History in Iran", Water and Sustainability in Arid Regions, Springer Netherlands, pp. 125-138, 2010.

[11] A. Salih, "Qanats a Unique Groundwater Management Tool in Arid Regions: The Case of Bam Region in Iran", International Symposium on Ground Water Sustainability (ISGWAS), Alicante, Spain, pp.79-87, (2006).

[12] H.E. Wulff, “The Qanats of Iran", Scientific American, pp.94-105, New York, USA, April 1968.

[13] D.R. Lightfoot, "The Origin and Diffusion of Qanats in Arabia, New Evidence from the Northern and Southern Peninsula", the Geographical Journal, vol.166, no. 3, pp. 215-226, 2000.

[14] M. Javan, A.M. Hassanli and M.A. Shahrokhnia, "The Ancient Qanats of Iran", In: Proc: $1^{\text {st }}$ IWA Int. Symp. Water and Wastewater Technologies in Ancient Civilizations, Iraklio (Greece), pp. 531-534, (2006).

[15] S.C. Stiros, "Accurate Measurements with Primitive Instruments, the "Paradox" In the Qanat Design", Journal of Archaeological Science, vol.33, no.8, pp. 1058-1064, 2006.

[16] L. Mays, "Ancient Water Technologies", $1^{\text {st }}$ Edition, Springer Dordrecht, the Netherlands, pp. 115-137, 2010.

[17] P. Magee, "The chronology and environmental background of Iron Age settlement in Southeastern Iran and the question of the origin of the Qanat irrigation system", Iranica Antiqua, vol.40, pp.217-231, 2005.
[18] G.L. Macpherson, W.C. Johnson and H. Liu, "Viability of Karezes (ancient water supply systems in Afghanistan) in a changing world", Applied Water Science, pp.1-22, 2015. [19] A. Himat and S. Dogan, "The Construction and Maintenance of Ancient Karez System", In: Proceedings: IWA $2^{\text {nd }}$ Regional Symposium on Water, Wastewater and Environment, Izmir, (Turkey), pp. 557-565, (2017).

[20] H. Weingartner, "Water supply by qanats: a contribution to water shortage in Mediterranean areas", In Proceedings of the 10th International Conference on Environmental Science and Technology, Kos island, Greece, pp. 5-7, (2007).

[21] B. Remini, B. Achour and J. Albergel, "The qanat of Algerian Sahara: an evolutionary hydraulic system”, Applied Water Science, vol.5, no.4, pp. 359-366, 2015.

[22] E. Hayat and A. Baba, "Quality of groundwater resources in Afghanistan", Environmental monitoring and assessment, vol.189, no.7, pp.318, 2017.

[23] D.R. Lightfoot, "Moroccan Khettara: Traditional irrigation and progressive desiccation", Geoforum, vol.27, no.2, pp. 261-273, 1996.

[24] S.A. Walters and J.W. Groninger, "Water distribution systems and on-farm irrigation practices: Limitations and consequences for Afghanistan's agricultural productivity", Water International, vol.39, no.3, pp. 348-359, 2014.

[25] B. Schultz, "Irrigation, drainage and flood protection in a rapidly changing world", Irrigation and Drainage, vol.50, no.4, pp.261-277, 2001.

[26] Z. Ruisen, D. Xinguang and M. Yingjie, "Sustainable water saving: new concept of modern agricultural water saving, starting from development of Xinjiang's agricultural irrigation over the last 50 years", Irrigation and drainage, vol.58, no.4, pp. 383-392, 2009.

[27] I.M. Anderson, "Rehabilitation of Informal Irrigation Systems in Afghanistan", Design Manual, $1^{\text {st }}$ Edition. United Nations Food and Agricultural Organization (FAO), Peshawar, Pakistan, pp. 68-95, (1993).

[28] A. Himat and S. Dogan, "Ancient Karez System as a Sustainable Tool for irrigation and Water Supply in Rural Afghanistan", International Journal of Ecosystems and Ecology Science (IJEES), vol.7, no.2, pp. 269-274, 2017.

[29] United States Geological Survey, "Geological map of Afghanistan", 2007. https://gcmd.nasa.gov/records/GCMD_ USGS_OFR_2007_1104.html (Accessed on March 20, 2018).

[30] D. Mustafa and M.U. Qazi, "Transition from Karez to tube well irrigation: development, modernization, and social capital in Balochistan, Pakistan", World Development, vol.35, no.10, pp. 1796-1813, 2007.

[31] M.J. Khan, G. Pacha, M. Shahzad Khattak and R. Oad, "Water distribution of traditional Karez irrigation systems in Afghanistan", Irrigation and Drainage, vol. 64, no.2, pp. 169179, 2015.

[32] R. Fu, M. Shadeer and R. Tiyipujiang, "Study Breaking Mechanism of Karez Systems in Turpan Basin", Procedia Materials Science, vol.3, pp. 1786-1791, 2014.

[33] UNHCR, "The UN Refugee Agency, Figures at a Glance", 2017. http://www.unhcr.org/figures-at-aglance.html (Accessed on March 24, 2018). 